http://dx.doi.org/10.4314/gjl.v5i1.73

\title{
"I AM SPEAKING FRENCH BUT I AM THINKING IN ENGLISH": AN ANALYSIS OF ERRORS BY STUDENTS OF THE FRENCH LANGUAGE AT THE UNIVERSITY OF GHANA
}

\author{
Sewoenam Chachu
}

\begin{abstract}
This paper is in the domain of language acquisition and more particularly foreign language learning using the theoretical framework of Error Analysis but also taking into account the concept of the development of Interlanguage during the learning of a foreign language. We consider how learners of French as a Foreign Language in the University of Ghana seem to fall, either consciously or unconsciously, on the English Language during their oral and written productions. For this study, first and second year students of French from the University of Ghana were given a series of images and asked either to describe what they saw and/or to use the images to tell a story or form a dialogue. It was observed that there was evidence of English structures, transpositions, transliterations, etc. in their productions. We consider that these interferences are part of the development of the Interlanguage of the learners and we examine some of the types of errors identified in the production of the students. We conclude that this is a natural process for the learner of a foreign language in a multilingual context and we consider how the teacher of a foreign language class can take advantage of these productions to improve his teaching and also improve learning by his/her students.
\end{abstract}

Key Words: Error analysis, transference, Foreign Language Learning, Interlanguage, English, French

L'article appartient au domaine de l'acquisition linguistique et plus particulièrement l'apprentissage de langue étrangère en se basant sur le cadre théorique de l'Analyse des Erreurs mais prenant aussi en compte le concept du développement de l'Interlangue pendant l'apprentissage d'une langue étrangère. Nous examinons de comment les apprenants du Français Langue Étrangère à l'Université du Ghana semblent avoir recours, soit consciemment soit inconsciemment, à la langue anglaise pendant leur production orale et 
écrite. Pour cette étude, on a donné aux apprenants en première et deuxième années de licence des images et on leur a demandé de raconteur une histoire ou de former des dialogues à partir des images. On a observé qu'il y'avait des éléments structuraux de l'anglais, des transpositions, des translitérations, etc. dans leurs productions. Nous estimons que ces interférences font partie du développement de l'Interlangue des apprenants et nous examinons quelques uns des types d'erreurs identifiées dans la production des apprenants. Nous concluons que l'Interlangue et les erreurs font partie du processus d'apprentissage d'une langue étrangère et nous considérons comment l'enseignant dans une classe de langue étrangère pourrait profiter de ces productions pour améliorer son enseignement et l'apprentissage de la langue par ces étudiants.

Mots clés: Analyse des Erreurs, transfert linguistique, Apprentissage d'une langue étrangère, Interlangue, Anglais, Français

\section{Introduction}

It is generally agreed that a foreign language learner does not enter the language classroom one day and come out the next as a near-native speaker. There is a developmental process which takes place over a long period of time and during this process, the learner may write or speak the language in a manner that is not considered 'authentic' by the native speaker. As time goes on and as the learner progresses in learning the language, the errors gradually reduce until the learner acquires near-native perfection. This transition between starting to learn the language and acquiring native-speaker proficiency is what is termed the Interlanguage. According to Saville-Troike (2006), Interlanguage demonstrates intermediate stages of L2 development. This interlanguage may be viewed either positively or negatively especially as there is usually the question of language transfer from the L1 with positive transfer being considered to aid language learning and negative transfer being considered a bane to acquiring the second language.

Research into learner errors in foreign language learning and into language transfer by foreign language learners has greatly developed since the 1970s with the works of Corder $(1967,1973)$ and Selinker (1972) who focused on the notion of interlanguage and who pointed out that L2 learners do not produce random mistakes and that their errors seem to be governed by certain rules linked to the underlying grammars of the learners. Their conclusion that language transfer is an integral part of L2 learning has been corroborated in more recent times by Dörnyei \& Scott (1997), White (2003), and Saville-Troike (2006). Indeed, past research also indicates that in a given situation, there are differences between the production of a learner and that of a 
native speaker when they attempt to convey the same meaning in the target language (Dörnyei \& Scott, 1997).

The purpose of this paper is to present some errors discovered in the oral and written production of students of some first and second year students of French as a Foreign Language at the University of Ghana, Legon; discuss what these errors reveal about transference and the development of Interlanguage; and find out how the Foreign Language teacher can take into account these errors in the classroom to make learning the foreign language more productive.

However, we will first consider the unique context of studying French in Ghana and the role of the English language and other languages spoken in Ghana.

\section{The status of the French language in Ghana}

The Ministry of Education, together with the French Embassy, has been supporting the teaching of French in Ghana since the 1980s (AFC, 2010). The French language has the status of being a Foreign language which is taught as a subject in schools from the Junior High School Level even though some private schools introduce it earlier - sometimes as early as crèche. The Government acknowledges the importance of learning the French language and the Government White Paper of the Education Reform Review Committee (Oct 2004) emphasized the Government's intention to ensure that French became a compulsory subject at the Senior High School (SHS) level and the efforts being made to ensure that the Junior High School (JHS) curriculum prepares students to meet this benchmark. Indeed, the Paper states that:

It is the decision of government that apart from assuring primary tongue proficiency in English by the end of Primary school, the study of French to working standard --- will also become compulsory in second cycle education .... and the Junior High School curriculum should accordingly work up to that policy (GOG, 2004, p. 30).

As of now, in practice, the French language can be chosen as an elective subject in the Senior High School after which the students can further their study of the language either in the university, training college, or some other institution of higher learning. In the wake of the desire for regional integration on an economic, political and social level, and, considering the fact that Ghana is surrounded by francophone countries, successive governments have expressed the desire for promoting and developing the teaching or learning of French in the basic and secondary schools as evidenced from the documents cited above. 


\section{The Role of the English Language in Ghana}

Ghana, like other African countries, is a multilingual society with a majority of the people speaking at least two languages. Especially in the urban areas, most people may speak a local language which may be considered a Primary Language or L1 as well as a vernacular language which is widely spoken in that area. Due to intermarriages between couples of different ethnic groups, some children, born into mixed linguistic families are either exposed to both the language of the father and mother (if both parents speak each other's languages), to one of the 'parental' languages (if one partner understands the language of the other but it is not reciprocal), or to a third 'neutral' language which serves as a point of communication between the two parents. In some cases, especially in urban Ghana, this neutral language tends to be the English language which has a particular status in the Ghanaian society. English serves as a mediator language and children born into these families end up being exposed to English as a first language (even if it is not a mother tongue per se).

In Ghana, the English language has the status of being the official language. It is the language of education, media, the judiciary and the legislature. The language policy in Ghana has been changed from having the first three years of basic education to be carried out in the local languages to using English only right from Primary 1 (Ameyaw-Akumfi, 2002). In the urban areas, children are taught in English sometimes right from crèche. For this reason, some children whose parents speak English to them in the house and who are also exposed to English right from an early age may be considered as having English as their L1 or their Primary Language as they speak this more fluently than the local language of the tribe or ethnic group of their parents. The English language also has the status, in Ghana, of being the main medium of official communication in a multilingual society.

\section{The importance of English in the foreign language classroom in Ghana}

Considering the fact that the foreign language classroom is a place of languages in contact and in context, it is not surprising that we often find more than one language at play - the language(s) the learner already speaks and the language that is being acquired. In this paper, we posit that learners of French in the University of Ghana draw a lot from their competence in the English language rather than from the local languages they speak. This may be due to several factors including the fact that they develop a meta-language for English that they may not necessarily have for their local languages. The basic structures of language are typically learnt in English 
more than in the local languages. Thus, while a pupil or student may be able to easily identify a noun, verb, adjective, etc. in English, he or she may not be able to do the same for his or her indigenous language. Also, some teachers of the French language rely on the English language to teach or explain certain points to the learners. Lastly, most of the available bilingual material for teaching and learning French are in English and French rather than in an indigenous language and French. For example, we have access to English-French dictionaries, manuals in English and French, audio materials in English and French etc. For this reason, the learner is also most likely to draw from English when there is a challenge with expressing himself/herself in French. This notion seems to be supported by our data since the instances of interference and transfers observed are from the English language rather than from the indigenous languages. For these reasons, we will systematically refer to the English language in this paper as the Source Language (SL) and French as the Target Language (TL). Where we refer to or quote an author, L1 should be understood as being the SL and L2 as being the TL.

\section{Interlanguage theory}

Developed by Selinker in the 1970s, Interlanguage theory is a branch of applied linguistics, and more particularly, language learning. In a nutshell, the theory posits that imperfect foreign language production by a learner gives rise to an intermediate language system which is a sort of 'third language' placed on a gradient between the two 'true' languages, i.e. the source language and the target language. According to Ellis (1997), Interlanguage refers to a systematic development of learner language reflecting a mental system of L2 knowledge. It involves the construction of a system of abstract linguistic rules by the learner. Such interlingual transfer is demonstrated in the types of errors committed by learners at either a phonological, morphological, grammatical, lexical or semantic level with the learner transferring such elements from the source language into the target language. When it comes to adult foreign language learning, which is the focus of this study, it has been suggested that an adult foreign language learner encounters competition between the new concepts with which he is confronted and the existing concepts from the L1. This can lead to restructurings in the L1 and in the L2 (Dewaele, 2002; Kecskes \& Papp, 2000). These restructurings are considered to be errors. It is important to draw the distinction between a mistake and an error when it comes to foreign language teaching and learning because the two are not interchangeable. The Dictionary of Language Teaching and Applied Linguistics (1992) describes mistakes in writing or speaking as being due to lack of attention, fatigue, carelessness, or some other aspects of performance. These can be self-corrected when the speaker becomes aware of them. 
On the other hand, an error implies using a linguistic item in a way that a fluent or native speaker regards as demonstrating faulty or incomplete learning. In other words, an error occurs because the learner does not know what is correct, and therefore there can be no self-correction in this case, whereas there can be self-correction in the case of a mistake. In error analysis, these errors are not regarded as the result of persistent old habits. They should rather be seen as signs that the learner is going through a process of internalization and investigation of the new language's system. Interlingual errors may occur at different levels such as transfer of phonological, morphological, grammatical and lexico-semantic elements of the native language into the target language.

Unfortunately, it has been observed that errors in the foreign language classroom, especially in our socio-cultural context, are frowned upon and sanctioned without taking into consideration the fact that it is a natural process of the language learning process and that the errors made by students could actually guide the teacher to prepare students to adequately cope with their difficulties. According to Dörnyei and Scott (1997, p.202) "L2 speakers spend a lot of time and effort struggling with language difficulties yet L2 courses do not generally prepare students to cope with performance problems". For this reason, it is necessary to study the errors made by students which can serve in (i) identifying strategies used by language learners (ii) identifying the causes of learners' errors (iii) obtaining information on common difficulties in language learning to aid in teaching or in developing teaching materials (Richards et al, 1992). We posit that it is only when a foreign language teacher understands the causes and reasons for the errors made by the learner that he or she can effectively teach the students to avoid such errors or remedy their linguistic inadequacies. It is for this reason that it is necessary to undertake error analysis as it enables researchers to focus on the errors made by a foreign language learner with emphasis on the significance of these errors for teaching and learning.

\section{Learning French in a multilingual African context}

Most of the research available in the field considered situations of bilingualism in which a learner is learning a foreign language in a western context in which there is just one source language and one target language. Even in cases where there is mention of multilingualism, the learner is still dealing with languages for which the learner has developed metalanguage. However, when it comes to learning English or French which may either have the status of a second language or a foreign language taught in school, the approach is different. Usually, the language is learnt in an exoglotic context and usually, the learner does not get exposed to the language outside the classroom. As Amuzu (2008) explains, French is not used as a means of 
communication once the students get outside the classroom. Also, a majority of students learning French in the Ghanaian context have not acquired the linguistic fundamentals, either in the indigenous languages or in English before they begin to learn French.

Amuzu (2008) hypothesizes that difficulties in learning the French language in a multilingual, non-francophone community may be due to three main reasons:

i. Mixing up internalized structures, especially as the students usually turn to their first language or the English language to conceptualize grammatical and lexical structures in French.

ii. The languages already acquired become a source of blockage for the students, mainly because the students have not mastered these languages especially when it comes to the written aspect.

iii. The third hypothesis is that one of the causes of transfer errors discovered in the production of students is due to the differences in structure at the level of phonetic/phonology, morphosyntax and lexis and semantics.

We tend to lean towards his third hypothesis for this paper, based on the observation that the students we observed had a mastery over the English language and also that the transfers we observed all seemed to be based on the structure of the English language.

\section{Methodology}

The sample for our study belongs to a class of students who have had their training in the English language and who are very comfortable using this language as a means of communication. Considering the fact that only the best get to enter the University, these students can be considered part of the elite for whom English plays a more important role than any indigenous language they may speak as far as their academic life is concerned.

A total of 100 first and second year students (18 to 20 years on the average) of the French department were recorded with their permission during an oral examination session in which they were asked to describe an image or form a dialogue (in pairs) from the image(s). Their productions were then transcribed. It is these errors that we analyze grouping them into various types of errors and discussing possible ways in which the foreign language teacher can use these errors to his advantage. In this article, we do not use phonetic transcriptions as our focus is more on structural observations. We transcribe the individual words as close to the sound as 
possible. We then analyze these productions using the classifications of student errors developed by Corder (1973).

He groups the errors produced by learners into four categories namely:

i. omission of some required element;

ii. addition of some unnecessary or incorrect element;

iii. selection of an incorrect element; and

iv. misordering of the elements.

Subsequently, Corder (1973) includes the morphology, syntax and lexicon as sub-areas of his four categories of errors linguistically speaking. In our paper, we combine the four categories and sub-categories in our description of the errors observed in the production of our students.

\section{Syntactic interference}

This type of error is demonstrated by the learner on the syntactic structure of the Source Language and thus the learner repeats this structure in the Target Language. The two main types observed in the production of the students were syntactic errors denoting the addition or omission of an element.

\section{Deux femmes différentes qui sont parler au téléphone (Deux femmes différentes qui parlent au téléphone) \\ 'Two different women who are speaking on the telephone'}

In example 1, the student adds sont to parler probably because in English the auxiliary to be is included in the conjugation of the verb in the present continuous tense. In French, the auxiliary is not used for this tense, which shares the same form as the simple present tense. Parlent could be translated speak or are speaking, meaning that there is no need to introduce the auxiliary in French.

2. La première femme est contente parce qu'elle est rit (La première femme est contente parce qu'elle $\varnothing$ rit)

'The first woman is happy because she is laughing.'

Example 2 demonstrates addition and misordering. It can also be considered a case of transliteration since the learner seems to have done a word-for-word 
translation from English. As in the case of example one, the conjugated form rit means is laughing. There is therefore no need to introduce the conjugated auxiliary est as this will mean *she is laughing.

\section{Elle $n$ 'est pas rit (Elle ne $\varnothing$ rit pas).}

'She is not laughing.'

In example 3, we observe the addition of the auxiliary être as well as a probable case of transliteration since the verb in French has been placed at the end of the sentence as is the case in English during negation. Normally in French, the verb is surrounded by the negation markers $\boldsymbol{n e}$ and pas. While in English, there is just one marker not and it precedes the verb.

\section{4. ...parce que les femmes sont toujours travaillent (parce que les femmes $\varnothing$ travaillent toujours). \\ '... because women are always working.'}

Example 4 presents a double scenario of the introduction of the auxiliary verb être as well as transliteration. This is because in French, the adverb toujours will be in final position but in English it precedes the verb. It is observed that the learner places it before the verb just as it occurs in English.

\section{Il y a une réunion sur lundi (Il y a une réunion $\varnothing$ lundi)}

There is a meeting on Monday

Example 5 demonstrates the introduction of the French preposition sur which is the translation of the English preposition 'on'. Most likely because in English the preposition appears before the day of the week, the learner has transposed this to the French language where there is no preposition before the day of the week. In certain contexts, there will be the definite article le/les.

Most of the errors observed for addition concern the auxiliary verb être. This is because in English, this auxiliary appears in constructions of the present continuous tense even though it does not appear in French. Moreover, the errors that are linked to the prepositions is also because in English 'on' appears before mentioning the day of the week in similar constructions.

\section{ii) Omission}

These involve the absence of certain items in the construction that should 
normally be present. The omission errors observed were basically the absence of prepositions or some verbs in French where these are supposed to be present as can be observed from the sentences in brackets. It is to be noted that in the English equivalents, these lexical items would normally be absent.

\section{On demande $\varnothing$ l'homme le prix (On demande à l'homme le prix).}

'They ask the man the price.'

In example six, the student omits the preposition à. In French, the verb demander is accompanied by the preposition $\grave{a}$ if it means to 'ask somebody'. However, in English, there is no preposition.

\section{Il $\varnothing$ besoin des stylos et des cahiers (Il $a$ besion des stylos et des cahiers).} 'He needs pens and exercise books.'

There is an omission of the auxiliary verb avoir in the example 7 since in English it is possible to conjugate need without using an auxiliary. However, there is the less-used equivalent 'He has need of,' which includes the auxiliary avoir, and which is syntactically closer to the French equivalent.

\section{Un homme entre $\varnothing$ le bus (Un homme entre dans le bus).}

'A man enters the bus.'

In example (8), the learner omits the preposition dans which usually follows the verb entrer. It is to be observed that in English, the equivalent verb 'enter' does not need to be followed by the preposition 'in/into.'

The general observation from the examples of the omission errors is that the learners borrowed from the English structure and did not include words that are expected to be present in French, basically because they are not present in English.

\section{Misordering}

In the error of misordering, the elements are structurally misarranged. These errors also demonstrate a dependence on the English language since the words are misordered based on the English structure. The following are some examples.

3. Elle n'est pas rit (Elle ne $\varnothing$ rit pas).

'She is not laughing.' 
Even though we have already seen example 3 as a case of addition of the auxiliary être, this example also presents an example of misordering. This is because the structural arrangement of the negation particles is patterned after the English structure of negation making it awkward and quite clumsy in French. The verb is in the final position as is the case in English.

\section{4. ...parce que les femmes sont toujours travaillent (...parce que les femmes travaillent toujours). \\ '... because the women are always working.'}

In example 4, we observed a misordering of the adverb and the verb. In the correct form in French, travaillent comes before toujours (...parce que les femmes travaillent toujours). However, in the correct form in English, it is the reverse with 'always' coming before 'working' (... because the women are always working).

\section{Elle veut savoir ce qu'ils ont besoin de (Elle veut savoir ce dont ils ont besoin). \\ 'She wants to know what they need/have need of.'}

Example (9) could be interpreted in three ways: The learner knows the expression avoir besoin de and therefore kept this form in the sentence without undertaking the necessary transformations using dont. It is also possible that the learner does not know how to use dont in such a case. Thirdly, the student could be relying on the English expression 'have need of' and transposing that structure onto the French sentence - (Elle veut savoir ce qu'ils ont besoin de).

\section{Je vais pour un romantique dîner (Je vais pour un dîner romantique).} 'I am going for a romantic dinner.'

Example 10 is a classic example of the challenges English language learners face with the position of adjectives in French. Whereas in English the adjective always precedes the noun, in French, it can either precede or follow it. And so, 'romantic dinner' has been transposed into French to produce romantique dîner.

For the cases of misordering, it is once again based on the structure of the English language and is expressed usually by transliteration where the learner does a word-for-word substitution from the English language to the French language. 


\section{Morphological errors}

These are errors that are linked to the form of a word or expression

\section{iii) Lack of contraction}

\section{1. À le restaurant (Au restaurant).}

'At the restaurant.'

\section{2. À le client (Au client).}

'To the client.'

We did not observe much by way of morphological errors in the productions of the students. The main challenge observed was the lack of contraction of the preposition + article in French and it is written out just like in English. This could also be due to trying to give a literal translation or just ignorance of the syntactic system of dealing with preposition + article in French.

\section{Lexical errors}

Errors based on the lexicon are usually either due to the fact that the learner does not know the right word to use and therefore fills the 'gap' with a word from L1 or uses a similar sounding word in L1 in a way that it is usually not used in L2. Some examples are presented below with the correct French rendition in parenthesis:

\section{False cognates}

13. Je n'ai pas l'intention de célébrer mon anniversaire. (Je n'ai pas l'intention de fêter mon anniversaire).

'I don't intend to celebrate my birthday.'

14. Une vielle femme achète les végétales. (Une vielle femme achète les légumes).

'An old woman is buying the vegetables.' 
15. Le professeur introduit elle pour la classe. (Le professeur la présente à la classe).

'The teacher introduces her to the class.'

The examples (13), (14) and (15) demonstrate what is called faux amis in French (false cognates). The learner uses célébrer, végétales and introduire because they sound like 'celebrate' and 'vegetables' and 'introduce' even though they do not mean the same thing in French.

\section{Mais Tom est peur (Mais Tom a peur).}

But Tom is afraid.

Example (16) is another example of the wrong use of vocabulary based on a direct translation from English to French. The learner uses the verb 'to be' instead of the verb 'to have' because that is what is used in English. Indeed, in English, the expression is 'to be afraid,' while in French, the expression used means to 'have fear.'

\section{Insertion of L1}

17. La maîtresse l'introduce à les enfants dans la classe (La maîtresse la présente aux enfants dans la classe).

'The mistress introduces her to the children in the class.'

In the example above, the student inserts the English word 'introduce' possibly because he or she does not know the alternative in French. Even in the case where there is a similar sounding word in French introduire, it does not mean 'to introduce someone to someone else.' It is used in contexts where it means 'to make enter,' for example 'He introduced the key into the door.' In French, the right word to use for introducing someone is présenter.

18. Elles checkent les heures que les enfants vont de la maison (Elles vérifient l'heure que les enfants quittent la maison). 
'They check the time that the children leave (from) the house.'

Example 18 seems to be a clear case of lack of vocabulary as the student reproduces an English word to fill a lexical gap.

19. Son chef est son mari et les customers, ses enfants. (Son chef est son mari et les clients ses enfants).

'Her chief is her husband and her customers her children.'

\section{Transliteration}

20. J'espere que tu vas venir encore (J'espère que tu vas revenir / J'espère que tu reviendras).

'I hope that you will come again.'

21. Et parce que de ce problème... (Et à cause de ce problème...).

'And because of this problem...'

(20) and (21) demonstrate another structural error where a direct translation seems to be made on a word-for-word basis from English to French. However, unlike the case of simple misordering, these errors are not only grammatical but also lexical as some words are used in the wrong context like parce que in 21. In such situations, the teacher needs to explain the different contexts in which words from similar semantic fields can be used. For example, à cause de/parce que. Learners may be taught for example that parce que cannot be followed by de while à cause de is a fixed expression. Secondly, in the example of (20), the teacher can explain how the French express doing something again by affixation $(r e+v e n i r=$ revenir $)$ while the English choose to use 'again.'

We observe that with the errors that have to do with the insertion of the L1, the learner fills a lexical gap with a word from English to make their sentence complete. These words are not introduced by a speaker who is bilingually competent but by a learner who clearly lacks vocabulary in the target language and is introducing vocabulary from the Source Language as a stop-gap measure. They are actually errors that are due to lack of vocabulary/expressions and in this case, the learner falls, once again, on the English language to fill in the gap. What is noteworthy is that in all the 
scripts that we analyzed, we did not find evidence of the learners using a local language where they had a gap. All the stop-gap vocabulary was from the English language.

\section{The relevance of the errors and Perspectives for teaching}

For the language teacher, especially one who speaks the source language of the learners, the errors described above are very instructive. They give some insight into the cognitive processes underlying the learning process and in most cases the teacher, if he speaks the same source language, will perfectly understand what the learner wants to communicate and this in spite of the errors.

What can the language teacher and the developer of language course content derive from these errors? It is obvious that students do not commit these errors because they want to. Seeing that these errors seem to occur on a large scale and are usually of the types discussed above, it is suggested that provision is made for such errors in developing course content and also in course delivery. Language teachers should take time out to sensitize their learners to these possible errors and provide strategies for helping learners to cope with potentially difficult-to-master elements that are due mainly to L1 interference.

With the error of addition, we infer from the production of the learners that they have copied the structure from the English language, where the verb "to be" is used as an auxiliary in the present continuous tense. It is therefore quite difficult for the learner to imagine, without being taught, that this is not the case in the French language. It is important to note that in the French language, the same sentence structure can either have a habitual meaning or a present continuous interpretation without the use of an auxiliary verb.

Therefore, an example such as:

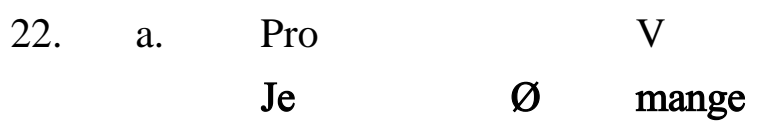

Can mean

$\begin{array}{ll}\text { b. Pro } & \text { V } \\ \text { 'I } & \text { eat' }\end{array}$

Or

c. Pro Aux V




$$
\text { 'I am eating.' }
$$

The learner, who is not aware of this difference and who usually thinks of what he or she wants to say in English before translating into French, will therefore borrow the Pro Aux $V$ structure from the English language to construct his or her sentences in French. In the second example of addition, we see that the learner adds a preposition like in English although no preposition occurs in French.

We propose that the teacher who observes such errors (wrongful addition of an auxiliary) should be able to undertake a contrastive analysis with the students to enable them understand the differences in conjugation in the present tense and the present continuous tense in English and the equivalent expressions in French. The learners should be able to undertake lots of structural exercises in French to enable them to grasp the fact that the equivalent of the present continuous tense in English is expressed without an auxiliary in French.

When it comes to lexical errors, especially errors with false cognates, the teacher can produce a list of words in English that sound like words in French and assign the students in groups or as individuals to go and search for the differences in meaning between the English and French equivalents. This will help the students also take ownership of their learning process and is likely to have a longer-lasting impact than just repeatedly marking them wrong without making any effort to remedy the situation.

A suggestion for dealing with the insertion of the L1 by the learner is to give the students more exercises in translation or to involve them in conscious vocabulary building where students are taught to make use of dictionaries (both hard and soft copies), expression and vocabulary books, etc. to build a solid vocabulary base in various thematic areas for example the home, shopping, cooking, introducing oneself, etc.

The teacher can remedy morphological error of lack of contraction (e.g. à $\mathbf{l e}$ restaurant instead of au restaurant) not just by having a grammar lesson to explain the contraction process but also by providing communication scenarios or exercises in which the learners will have to use these forms to such an extent that the learners get used to these forms and assimilate them till it becomes an unconscious gesture.

When it comes to errors of omission, the French language teacher has to help the students learn expressions in the language instead of individual words so that the learner understands that certain words go together even if that is not the case in the English language. For example, in the case of (6), the learner has to learn that demander is usually followed by the preposition à, thus giving us the expression demander à quelqu'un as opposed to 'ask $\emptyset$ somebody.' The teacher can also teach the students, in the case of the error in (7), that in French the expression avoir besoin de is 
more or less equivalent to the English 'have need of' since in French you cannot just 'need something' but you 'have need of something.'

Lastly, the teacher needs to explain to the learner that in an example like (8), entrer, as a verb movement is always followed by the directional preposition dans. This will enable him explain to the students. It is important for the teacher to explain not just grammatical rules but the concepts behind the rules to make learning easier for the learners, especially where there is a conflict with the concept from the source language.

When tackling the error of misordering, especially for a foreign language teacher who speaks the same Source Language as the learners, the teacher can undertake a contrastive analysis with the students and also expose them to the language in use by discussing the perceived differences in the structure of French and English such as the position of adjectives, etc.

\section{Conclusion}

What do these findings mean for the foreign language teacher? Firstly, we will say that it calls for another look at student errors knowing that they are not always due to negligence on the part of the student. Many times, these so-called errors actually point to creativity on the part of the learner - be it morphological, syntactic, or even discursive. They actually point to the learner making an effort to manage language problems and difficulties which Dörnyei and Scott (1997) describe as a salient part in L2 communication. It is also important for a teacher to make an effort to incorporate these communication strategies into their teaching and learning objectives. These findings are also a useful tool for devising or designing more adequate methodologies for the classroom and new and improved teaching materials.

An understanding of these errors, based on the Source Language, can also help the teacher offer remedial teaching, explaining the source of these errors so that students are aware of them and pay particular attention to them. Indeed, interference and transfers are a normal part of second or foreign language learning. It does not need to be a source of frustration for the teacher but rather a window through which the teacher can observe the gaps that need to be filled. Learners will master the target language as they gradually internalize the syntactic structures of the target language and learn to think in that language. If such errors are well handled, they can actually lead to rapid progress by the learners as they master the intricacies of the target language and learn to distinguish the differences and/or similarities between the Source language and the Target Language. 


\section{References}

Ameyaw-Akumfi, C. (2002). English only, no more vernacular. People's Daily Graphic. Accra, Ghana.

Amuzu, D. S. Y. (2008). Problèmes de Transfert Linguistique Inhérents à l'Apprentissage du Français dans un Milieu Multilingue Non-francophone. Teaching and Learning of Language, Culture and Literature, 67-81.

Associates for Change (2010). The Status of French Language Teaching and Learning across Ghana's Public Education System.

Corder, S. P. (1967). The significance of Learner's errors. International Review of Applied Linguistics in Language teaching. Volume 5, No.4. 161-170 (AF)

Corder, S. P. (1973). Introducing Applied Linguistics. Penguin Education.

Dewaele, J.-M. (2002). Variation, chaos et système en interlangue française. Acquisition et Interaction En Langue Étrangère, 17, 147-167. Retrieved from https://aile.revues.org/1030

Dörnyei, Z.; Scott, M. L. (1997). Communication Strategies in a second language: Definitions and Taxonomies. Language Learning, 47(1), 173-210.

Ellis, R. (1997). Second Language Acquisition. Oxford: Oxford University Press.

Government of Ghana. (2004). Ghana Education Review Report: White Paper.

Improving Educational Quality (IEQ) Project. (2000). Implementation of the School Language Policy in Ghana: Interim Report. Retrieved from http://www.ieq.org/pdf/interim_ghana.pdf on 15th April 2015.

Kecskes, I., \& nde Papp, T. (2000). Foreign language and mother tongue. Psychology Press.

Richards, J. C. et al. (1992). Dictionary of language teaching and applied linguistics. Essex: Longman.

Saville-Troike, M. (2006). Introducing Second Language Acquisition. Cambridge: CUP.

Selinker, L. (1972.) Interlanguage. International Review of Applied Linguistics 10: 209-241.

White, L. (2003). Second Language Acquisition and Universal Grammar, Cambridge: CUP. 